\title{
Avrupa Para Birliği'nin Sorunlu Dinamikleri ve Yunanistan Borç Krizi
}

\author{
Zeki İlker GÖRENEL*
}

Öz

Bu çalışmada, Avrupa Birliği üyesi Yunanistan'ın 2008 yılında başlayan dünya finansal krizi sonrasında yaşadı ̆̆ ekonomik sorunlar ele alınarak değerlendirilecektir. Öncelikle Avrupa Para Birliği (APB) ve Avrupa Merkez Bankası'nın (AMB) uyguladıkları politikalar ve ekonomi politikaları ilkeleri çerçevesinde para birliğine dâhil olan farklı ekonomik gelişmişlik düzeyindeki ülkelerin temel ekonomik göstergeleri üzerinde ne gibi etkileri olabileceğine dair teorik bir çerçeve çizilecektir. Ardından bu yapı içerisinde yer alan ülkelerden Yunanistan'ın, birliğe hangi ekonomik koşullar ve yapı altında girdiği, sonrasında ise ne tür politikalar takip ederek "Avro Bölgesi"nden çıkma alternatiflerinin bile dile getirildiği duruma nasıl geldiği tarihsel olarak incelenecektir. Krizi ortaya çıkaran temel dinamiklerin Yunanistan'a özgü siyaset yapma biçimi, ekonomi üzerinde etkili olan hâkim grupların davranışları, ekonomik altyapı yetersizlikleri gibi içsel nedenlerden mi yoksa AMB politikaları gibi dış dinamikler nedeniyle mi geliştiği yönündeki tartışmalar değerlendirilerek analiz edilecektir.

Anahtar Kelimeler: Yunanistan Borç Krizi, Avrupa Para Birliği, Troyka, Avrupa Merkez Bankası, Merkez-Çevre Politikaları

\section{The Problematic Dynamics of European Monetary Union and the Greece Debt Crisis}

\begin{abstract}
This article evaluates the economic problems of Greece, a member of the EU, following the world financial crisis of 2008. It attempts to draw a theoretical framework on how policies of European Monetary Union (EMU) and the European Central Bank (ECB) may affect the economies of the Eurozone member countries with different levels of economic development. It specifically takes the economic conditions and the policies followed by Greece before and after the EMU membership into consideration in a historical manner. Also this article reviews the discussion on the

*Yrd. Doç. Dr., Marmara Üniversitesi, İktisat Fakültesi, İktisat Politikası Anabilim Dalı, E-posta: zekigorenel@hotmail.com
\end{abstract}


basic dynamics and reasons that led to the sovereign debt crisis, namely, whether the internal factors (such as policy style of Greece, the effects of interest groups, or inefficiencies of the economic structure, etc) or the external factors (such as policies of EMU).

Sayfa/Page | 172

İGÜSBD

Cilt: 2 Sayı: 2 Ekim / October 2015

Keywords: Greece Debt Crisis, European Monetary Union, Troika, European Central Bank, Center-Periphery Policies

\section{Giriş}

Küreselleşme dalgası, liberal demokratik devletlerin kendi ekonomilerinin yönetimi gibi en önemli geleneksel fonksiyonlarını ve yürütme kapasitelerini azaltmıștır. Öncesinde kendi geleceklerini belirleme yeterliliğinde olan devletler, küresel güç hiyerarşisinin, dünya ekonomisinin yeni düzeninin, uluslararası rejimler ve organizasyonların, uluslararası hukukun ve anlaşma taahhütlerinin varlığı arasında belirlenmiş koşullara ve kısıtlamalara bağlı hale gelmişlerdir. ${ }^{1}$

Küreselleșme karşısında bölgeselleşmenin temsili olan Avrupa Birliği'nin çevresinde bulunan İspanya, Portekiz ve Yunanistan'ın birlik ile bütünleşmeleri için gerekli kriterlere ulaşmaları esnasında uyguladıkları politikalar da Avrupa Birliği tarafından önerilmiş, denetlenmiş, kriterler tespit edilmiş, bu politikaların ele alınıp yürütülebilmesi için kurumsal destek ve finansman sağlanmıştır. İlerleyen yıllarda parasal birliğe geçiş ile birlikte, üye ülkelerin belirli ekonomik faaliyetlerdeki özerklikleri azalmış ya da ortadan kalkmış, ilişkili politikalar merkezileşmiştir. Ülkeler açısından bakıldığında da $\mathrm{AB}$ ile bütünleşme bu ülkelere piyasa rasyonalitesi yüklemiş, ülkelerin yaşamış oldukları sorunlar için² en güvenilir ve en etkili çözüm olarak görülmüş ve katılım ile ilgili sosyoekonomik ve siyasi reform gereklilikleri, bu ülkelerin gelişmelerinde önemli bir ivme haline gelmiştir. ${ }^{3}$

Çevredeki bu ülkelerin, uzun bir ekonomik korumacılık ve otarşi deneyimleri bulunmaktadır. Ekonomileri "rekabetçi" bir kapitalizmden öte "desteklenen" kapitalizme daha yakındır. 19. yüzyıldan beri bu ülkelerde

${ }^{1}$ Held ve McGrew, 1993, s. 265.

2 Maravall, 1997, s. 140; Yunanistan'da 1981 yılında kişi başına GSYIH, Avrupa ortalamasının \%58'idir; ticaret ve endüstri ileri düzeyde korunmaktadır, emek piyasaları oldukça katıdır. Hızla değişen uluslararası çevrede ekonominin rekabetliliğinin düşüşü sorunuyla karşı karşıya kalınmıştır. 1980 başlarında GSYİH büyüme oranı on yıl öncesinden üç kat daha düşüktür ve işsizlik iki katına çıkmıştır. Yunanistan'da kamu harcamaları 1970 ortalarından sonra yükselmeye devam etmiş; bütçe açılkarı kamu borcuyla finanse edilmiştir.

${ }^{3}$ Henig, 1972, s. 185. 
devlet ve kamu girişimleri ekonomik gelişmenin sağlanmasında önemli bir rol oynamışlardır. Devlet merkezileşirken, kamu bürokrasisi de büyümüş ve etkinsizleşmiştir. Haliyle zayıf kapitalizmin sonuçlarıyla, yüksek enflasyon, giderek büyüyen kamu açıkları, rekabetçi olmayan bir tarım sektörü, yüksek işsizlik, azgelişmiş bir refah sistemi, etkin olmayan kamu sistemi, yüksek dış açıklar ile karşı karşıya kalmışlardır. Üyeliğe uyum için gerekli reformlar ile uluslararası piyasalarda rekabet edebilir bir düzeye, ödeme gücüne ve bununla ilişkili güvenirliliğe ulaşmak amaçlanmıştır. ${ }^{4}$ Dolayısıyla 1980’ler boyunca ekonomik modernizasyon yurtiçi politikalarda anahtar kelime olmuş, modernizasyon Batı Avrupa'yı yakalamak anlamına gelmiştir.

Bir yandan ortak pazara ve parasal birliğe dâhil olmanın getirilerinin ne olacağını bilen ve yıllarca deneyimleyen bir çevre ülkesi, diğer taraftan politika belirleme, yürütme, izleme ve denetleme erkine sahip merkezileşmiş bir birlik. Yunanistan'ın üyeliğini dahi sorgulanır hale getiren altı yıldır çözülemeyen ve daha da derinleştiği izlenen bir ülke krizi gerçeği karşısında şu sorular çıkıyor ortaya: Avro bölgesi ekonomi yönetimi merkez ve çevre ülkeler arasında ortaya çıan cari işlemler dengesizliklerini neden göz önüne almadı? APB'ne dâhil çevre ülkelerinin düşük faiz oranları ile karşı karşıya kalmalarının tüketim ve yatırım patlamalarına ve cari işlemler açıklarına yol açacağı neden öngörülemedi? Yatırım artışlarının verimliliği artıracağı, bunun da ticaret dengesini iyileştireceği ve faiz ödemelerinin bu iyileşme sayesinde sorun çıkarmayacağı mı düşünüldü? Finansal entegrasyonun açık ve fazlaya sahip üye ülkelerin bankacılık sistemleri arasında karşılıklı bir bağ yaratacağı öngörülebileceği halde böylesi bir krizin yayılma riski neden algılanmadı?

Çalışmada öncelikle 1990 sonrasında Yunanistan'ın bütünleşme yönünde uyguladığı reformlara ve bu süreçteki ekonomik göstergelerine genel olarak değinilecektir. Ardından yaşanan krizde Yunanistan'ı ve ABP'ni sorumlu tutan karşıt yaklaşımların argümanları ele alınacaktır. Buradan referans ile para birliğinin yapısal mantığı sorgulanacak, birliğin biçimlendirilmesi esnasında ve birlik sonrası uygulanan politikaların ürettiği sorunlu dinamiklerin neler olduğu, ne tür etkilere yol açtığı tartışılacaktır. Yaklaşımı desteklemek üzere merkezde ve çevrede yer alan ülkelerin birlik öncesi ve sonrasındaki temel ekonomik göstergeleri değerlendirilecektir.

\section{Bütünleşme Yolunda Reformlar, Ekonomide Yaşanan Gelişmeler}

1981'deki tam üyeliğin ardından, 1990'ların ortalarından itibaren APB'ne katılım Yunanistan'ın stratejik hedefi haline geldi. "Sosyal devlet" söylemleri, "güçlü Yunanistan" ve APB'nin Yakınlaşma Programı'nın

${ }^{4}$ Holman, 1996, s. 130. 
Sayfa/Page | 174

İGÜSBD

Cilt: 2 Sayı: 2 October 2015

sağlayacağı ekonomik kazanımlar söylemleriyle yer değiştirdi. Ekonomik bütünleşme sürecini derinleştirmek üzere bir dizi karar alındı. Bu kararların ulusal düzeyde etkileri sadece her ülkenin piyasalarının yapısal özellikleri tarafından belirlenen başlangıç koşullarına değil, aynı zamanda değişen dış koşullara karşı politik, toplumsal ve ekonomik sistemin potansiyel olarak uyum sağlayabilirliğine ve ayarlamalarına da dayandırılmaya çalışıldı. ${ }^{5}$ Diğer taraftan ulusal hükümetler karşısında Avrupa Birliği Komisyonu, Avrupa Konseyi, Avrupa Parlementosu gibi Avrupa kurumları da güçlendiriliyordu.

Birliğe üyelik çerçevesinde sermaye ve emek hareketliliği üzerindeki engeller kaldırılmış, özellikle bankacılık ve sigortacılık olmak üzere hizmetler serbestleştirilmiş, yönetimsel ve yasal engellere karşı pek çok standart ve düzenlemelerle uyum süreci yürütülmüştü. Beklentilerden biri, finansal sermayenin merkez ülkelerinden $\mathrm{AB}$ içindeki çevre ülkelere yönlenmesi, bu yönlenmenin yatırımları hızlandırması, verimliliğin bu sayede artarak üyeler arasındaki farklılıkların azalmasıydı. Parasal birliğe yönelik olarak da ekonomik ve finansal politikaların uyumu gerçekleştirilmiş, mali politikalar ile döviz kurları üzerinde kısıtlamalar kaldırılmış, faiz oranları düşürülmüştü.

Yunanistan'da 1995-2008 arası dönem kredi liberalizasyonu, otoyollar, köprüler, inşaat gibi kamu altyapı yatırımlarının artışı, borsanın yükselmesi, ekonominin finans piyasalarına yönelmesi, gayrimenkul, turizm, ulaştırma gibi hizmet sektörlerinde patlama, kamu hizmetlerinin özel söktöre sözleşmeler vasıtasıyla devri, banka ve kamu şirketlerinin özelleștirilmeleri ile karakterize edilir. Bu politikalar sonrasında Yunanistan, sözkonusu dönemde ortalama \%3.7 ile $\mathrm{AB}$ içindeki yüksek büyüme oranlarından birine ulaştı. Bu yüksek büyüme iki faktöre dayanıyordu. ${ }^{6}$ İlki 1995-2004 yılları arasında 18 AB ülkesinden çok daha yüksek olan, \%30 civarında emek verimliliğindeki artıştı. $\mathrm{Bu}$ artış ithal edilen, değer yaratan teknolojilere ve mekanik malzemelere yönelik yatırımların artmasıyla ilişkiliydi. İkincisi ise düşük faiz oranlarının aşırı borçlanmaya neden olması, bunun da bankacılık sektörünün aşırı genişlemesine yol açan ekonominin finansal sektöre yönelmesinin yoğunlaşmasıydı. Bu iki faktör yurt içi talebi, üretimi ve tüketim malları ithalatını artırdı; avro'nun değerlenmesi nedeniyle ihracat piyasasında rekabet sınırlandığından mal ve hizmetler dengesi kötüleşmeye başladı. Diğer taraftan bankalara, deniz ulaşımı sermayesine ve yüksek gelirlilere vergi ayrıcalıkları sonucunda 2000'de GSYİH'nın \%43'ü seviyesinde olan kamu gelirleri, 2007'de \%37.3'e düştü. Bu tablo ülkenin yükselen borçluluğuna katkı sağlamış oldu.

${ }^{5}$ Katseli, 1990, s. 251.

${ }^{6}$ Markantonatou, 2012 s. 304. 
Diğer taraftan APB'ne geçtikten sonra, bütçe uyumu hedefi için kamu harcamalarını kısmaktan ziyade vergi artışlarına ağırlık verildi. 1993-2000 arasında vergi gelirlerinin GSYİH'ya oranı \%8 artarken kamu harcamalarının oranı neredeyse aynı kaldı. APB'nin “yumuşak koşulluluğu” sürdürdüğü yıllar boyunca, 2008 krizine kadar toplam kamu harcamaları \% 43-45 arasinda seyrderken, vergi gelirleri 2000'de \%42.9'dan 2007'de \%39.6'ya düştü.7 APB sonrasında faiz dışı harcamalar, faiz oranları dönem boyunca düşüş gösterdiğinden oran olarak pek fazla değişiklik göstermese de artmış oldu.

\section{Borç Krizi ve Kriz ile Birlikte Ortaya Çıkan Tartışmalar}

Yunanistan'ın 2009'da karşı karşıya kaldığı ekonomik kriz, topluluk kriterlerine uyulmayarak izlenen sorumsuz maliye politikalarının yol açtığı, "devletin borç krizi" olarak tanımlandı. Basında "Yunan Tragedyası" ifadeleriyle durum dramatikleştirildi. $\mathrm{Bu}$ yaklaşımla krizi açılamaya çalışanların tartışmaları aşağıdaki nedenlere odaklanıyordu:8

Ekonomik faktörler olarak; piyasa fiyatları üzerinden yüksek kar marjları elde ediliyor bu da rekabet edebilirliği bozuyordu. Vergilenmeden kaçma-vergi kaçırma eğilimi uzun yıllardır kronikleşmişti ve giderek de yaygınlaşıyordu. Kaynağı sürdürülemez olan primlere dayanan yaygın erken emeklilik sistemi, bütçe açıkları üzerinde sorun teşkil ediyordu. Siyasi faktörler olarak ise AB fonlarının keyfi kullanımı, rüşvet skandalları, rekabet edebilirliğin kaybına neden olan aşırı bürokrasiyle birleșen uzmanlaşmanın yitirilmesi, yapısal reformlar ve modernizasyona karşı duran bir bürokrasi sıralanıyordu. Kronik siyasi yozlaşmanın sonucu olarak şişirilmiş ve etkin işlemeyen kamu sektörünün varlığı ile toplumsal olarak da geniş kitleler siyasetten ve ekonomiden dışlanarak marjinalleştirilmiş, refah fonksiyonları giderek zayıflatılmıștı. Ayrıca Yunanistan, Avrupa kurumlarına beyan ettiği istatistiki veri ve ekonomik göstergeler üzerinde de oynuyordu.

\footnotetext{
7 Katsimi ve Moutos, 2010, s. 573; harcamaları kısmanın siyasi maliyeti vergileri artırmanın siyasi maliyetinden daha fazlaydı; öncelikle vergi artışları dolaylı vergiler üzerineydi ve mali bir ilüzyon yarattığından tepki çekmiyordu. İkinci olarak, vergi artışının maliyetleri tüketiciler üzerinde etkili oluyor olsa bile harcamaların büyük kısmı belirli çıkar gruplarına yapıldığından partinin meşruiyetini zedeleyebilirdi. Üçüncüsü ise rant kollama ve vergiden kaçınma oldukça yaygındı (2006'da GSYIH'nın \%3,4'ü; vergilerin \%30'u) ve bu uygulamalardan yararlananlar kamu harcama kesintileri yerine vergi artışları için siyasi güçlerini kullanıyorlardı.

Bu sayede seçmenler oy verirken kamu açılarının artmasından etkilenmiyorlardı; politikanın mali sıkılık gerektirdiği durumlarda politika maliyetlerini çok az üstleneceklerine inanıyorlardı.

${ }^{8}$ Kitomilides, 2013, s. 630.
}

Sayfa/Page | 175

İGÜSBD

Cilt: 2 Sayı: 2

Ekim /

October 2015 
Sayfa/Page | 176

İGÜSBD Cilt: 2 Sayı: 2 Ekim / October 2015

Ülkenin ekonomik karışıklığının, bu iç yapısal sorunların ve devletin sorumsuz borçlanmasının kaçınılmaz sonucu olduğu vurgusuyla merkezdeki kurumlar (Troika: Avrupa Komisyonu, Avrupa Merkez Bankası ve Uluslararası Para Fonu) kamu harcamalarında ciddi kısıntılar, vergi artırımları, esnek emek piyasası gibi düzenlemeleri içeren kemer sıkma politikaları yoluyla hükümet borçlarının azaltılmasına yönelik politika önerilerinde bulundular. ${ }^{9}$

Diğer taraftan Avro bölgesi içindeki makroekonomik dengesizliklerin birbiri ile içiçe geçmiş yapısı göz ardı edildiğinden, bu durumun salt ödemeler dengesi krizi olarak tanımlanması gerektiğine dair karşı argümanlar da üretildi. ${ }^{10}$ Yukarıda bahsi geçen, ülke içi yapısal sorunların borç krizinde belirgin bir rolü vardı ancak krize yol açan temel neden, 1999 yılında hayata geçen parasal birliğin "biçimlendirme hataları" idi. 2008 küresel krizin kamu finansmanı üzerindeki olumsuz etkileri yaşanmaya başlandığında, bu sorunlu dinamikleri barındıran yapının bu tür şoklara karşı ne denli korunmasız olduğu görüldü.

Ortak para sistemi, merkez ve çevredeki ülkeler arasındaki asimetriyi parasal birliğin oluşumu öncesindeki duruma göre mutlak anlamda bozmuștu. AMB bütün bölge için tek bir faiz oranı belirlediğinden, öncesinin yüksek enflasyonlu ülkeleri reel ve nominal faiz oranlarının düşüşünden fayda sağlamış oldu. Çevre ülkeler için borçlanmanın maliyeti azaldığından cazibesi giderek arttı. Düşük büyüme oranları nedeniyle kuzeydeki merkez ülkelerden, yüksek büyüme oranlarını yakalayan çevredeki ülkelere doğru sermaye akımları hızlandı.

Sermayeye bu şekilde göreceli kolay ulaşabilen Yunanistan gibi çevre ülkelerde, ticareti olmayan yurtiçine yönelik gayrimenkul ve inşaat gibi sektörlerde tüketim ve yatırım artış gösterdi. Bu sektörlere yönelen fon girişleri, dış borçlarını geri ödeyecek yeterince kaynak yaratmadığı için sorun teşkil eder oldu. Diğer taraftan sermaye, ihracata dönük sektörlere de yönelmediğinden, bu ekonomilerin inovasyon ve etkinlik kazançları yoluyla uzun dönemli rekabet güçlerini de iyileştirmedi. Tek Avrupa Pazarı'nda daha fazla sermaye hareketliliği reel ekonomide daha fazla etkinlik üretemedi, kaynak dağılımını etkinsizleştirerek aksine piyasa başarısızlıklarına yol açtı.

\footnotetext{
9 Visvizi, 2014, s. 338; Öncelikle 2010 sonrasında EUP (Ekonomik Uyum Politikaları) uygulamaları ve gözetimi sonucunda Yunan ekonomisi \%20'nin üzerinde daraldı, 260.000 şirket kapandı, 2008 ile karşılaştırıldığında yatırım düzeyi \%86 düştü, 2014 başlarında işsizlik \%28'i aşt (gençler arasında bu oran \%63'e çıktı). Toplumun geniş kesimlerinde vergilendirmedeki sürekli artışlar ve bu politikaların ne zaman sona ereceği ve sonuçta ne olacağına dair belirsizlik hali sabrın tükenmesine neden oldu. ${ }^{10}$ Kaelberer, 2012, s. 423.
} 
Borç krizi tanımından yola çıkarak durumu değerlendirenlere karşı, eğer Yunanistan tarzı yaşam biçiminin böyle bir krize neden olduğu ileri sürülüyor ise İrlanda, İspanya ve Portekiz'in mali savurganlık ile kurumsallaşmış vergiden kaçma tavrı olmadığından krize girmemeleri gerektiği savunusu yapıldı. Ayrıca 2007 öncesinde sadece Yunanistan'ın büyük kamu açığı ve borç sorunu bulunurken, İspanya ve İrlanda'nın bütçe fazlaları mevcuttu. Kriterlere uymama konusunda yöneltilen eleştiriler için de, 2000'lerin başlarında faiz oranları artışı ile ekonomik büyüme yavaşlayınca, açıklarını artırarak İstikrar ve Büyüme Paktı kriterlerine uymayan Almanya ve Fransa örneği vurgulanır oldu. Ayrıca Michael-Matsas ${ }^{11}$ Yunanistan'ın, Avrupa bölgesinin GSYİH'sının sadece \%3'ünü oluşturduğunu, ekonomisinde yaşanan bu tehlikenin, borç verenlerin öncelikli olarak Fransız, İsviçre ve Alman bankaları olmaları nedeniyle yayılma, bulaşma etkisi gösterebileceği ihtimali olmasa, bu denli dikkate alınmayabileceğini de ileri sürer.

Kriz başladıktan sonra daha da derinleşmesine yönelik olarak, her ne kadar Yunanistan'ın eksiklikleri ve başarısızlıkları olsa dahi AB'nin (Avrupa Birliği Bakanlar Konseyi ve Avrupa Merkez Bankası) erken ve etkin biçimde müdahalesinde gecikmenin de etkili olduğu dile getiriliyordu. Ayrıca AB sorunu doğru tespit edememiş, bütçe konsolidasyonu ve politika reformunu içeren bir politikayı süratle devreye sokamamıștı. ${ }^{12}$ Bununla beraber IMF'nin Troyka'ya dâhil edilmesi, Avro sistemininin yönetimi konusunda şüpheleri de ortaya çıkarmıştır. Bütün bunlar, piyasaları ikna etme ve müdahalenin maliyetini de (Yunanistan'a Mayıs 2010'da 110 milyar EUR, Avro sisteminin geneline de 750 milyar EUR) artırmıştır.

\section{Para Birliği'nin Yapısal Mantığı ve Biçimlendirme Hataları}

2008'deki küresel finansal krizin Avrupa ekonomisi üzerindeki etkilerinin yaşanmaya başlamasıyla, parasal birlik de sorgulanmaya başlandı. Parasal birliğe geçiş ile birlikte karşılaşılabilecek sorunlar, bu sorunların etkisini ‘önleyici kuralların' belirlenmesi ve işletilmesi nedeniyle minimize edilecekti. Ancak finansal kriz sonrasında birliğin hızlı tepki verememesi ve ele aldığı politikaların da çözüm üzerinde beklenen etkileri sağlamaması merkezi bir aksiyon kapasitesinin olmadığı, politika tedbirlerinin 'önleyici' olmaktan uzak olduğu yönünde tartışmaları da beraberinde getirdi. ${ }^{13}$

Parasal birlik daha geniş çaplı ekonomik ve siyasi entegrasyon için gerekli adımlardan biriydi. Başlangıçta üye ülkelere herhangi bir kurtarma

11 Michael-Matsas, 2010, s. 496.

12 Tsarouhas, 2012, s. 87.

13 Featherstone, 2011, s. 201. 
Sayfa/Page | 178 İGÜSBD Cilt: 2 Sayı: 2 October 2015

programı ile yardım edilmeyeceği, hiç bir ülkenin Avro bölgesinden çıkmasına ve taahhütlerin yerine getirilmemesine izin verilmeyeceği gibi temel prensipler üzerine inşa edilmeye çalışılmıştı. ${ }^{14}$ Uygulamanın, birliğe üye ülkelere sağlayacağı en önemli kazanımın, kendi ulusal paralarına karşı oluşacak spekülatif faaliyetleri ortadan kaldıracağı düşünülüyordu. $\mathrm{Bu}$ uygulama ile birlikte görece zayıf ulusal paraya sahip ülkeler, önemli bir ekonomik çaba göstermeden kendilerini düşük faiz oranlarının geçerli olduğu bir yapıda bulmuş oldular.

Parasal birlik öncesindeki rejimde, Avrupa Para Sistemi'nde güçlü ulusal parası ve düşük enflasyonu nedeniyle Almanya, sistemin faiz oranı tabanını belirlemede etkiliydi. Kendi ulusal önceliklerine göre etkide bulunuyor, diğer ülkeler de makroekonomik politikalarını buna göre ayarlıyorlardı. $\mathrm{Bu}$ sistemde denge, nominal döviz kuru değişiklikleriyle sağlanıyorken, parasal birliğe geçiş ile birlikte bu uygulama seçeneği de ortadan kalkmış oldu.

Merkezin, özellikle Almanya ve Fransa'nın, Yunanistan ve diğer çevre ülkelerinin yaşadığı krizi "ülke borç krizi" olarak algılamaları ve süreci bu algıya odaklanarak yürütmeye çalışmaları, parasal birliğin kendi iç yapısının sorunlu dinamikler ürettiği konusunda karşı argümanları da üretti. $\mathrm{Bu}$ argümanlar şunlardı: ${ }^{15}$

- Avrupa Merkez Bankası, para politikasında faiz oranlarını, farklı üye ülkelerin ekonomik koşullarını göz önüne almadan "tek beden herkese uyar" yaklaşımıyla belirliyordu.

Farklı dönemlerde İrlanda, İspanya, Portekiz ve Yunanistan'da faiz oranları oldukça düşük seyretmiştir. Düşük faiz oranları finansal piyasalar tarafından döviz kuru riskinin yanlış fiyatlandırılmasıyla birleșince (ki bu durum Yunanistan'a borç vermenin, Almanya'ya borç vermeyle aynı riski taşıdığı anlamına gelir) bu ülkelerin kamu ve özel sektörlerinde aşırı borçlanmaya neden olmuştur.

- Üye ülkeler arasında ekonomik uyum eksikliği bulunmaktadır.

Avroya geçiş sonrası ilk onyılda cari işlemler dengesizlikleri görülmüştür. Ülkelerin ücret maliyetlerindeki farklılıklar rekabet durumlarını etkilemiş, bunun sonucunda da doğal olarak bazıları dış açık, bazıları da dış fazla vermiştir. $\mathrm{Bu}$ durum reel ekonomide karşılaşllan dengesizliklerin, finansal sektöre de yansıyacağını göstermiştir. Örneğin, Almanya 1999-2007

${ }^{14}$ Tsarouhas, 2012, s. 87.

${ }^{15}$ Kitomilides, 2013, s. 629. 
arasında ücretleri baskılayabilmiş, verimliliği artırabilmiştir. Ancak Güney Avrupa ülkelerinin aynı uygulamayı gerçekleştirememeleri, cari işlemler dengesizliklerine neden olan rekabette dengesizlikler üretmiştir. Kıbrıs, Malta, Slovenya, Yunanistan, İtalya, Portekiz ve İspanya'nın cari işlemleri ortalama olarak 1994'te GSYİH'nın \% 0.1 fazladan, 2008'de \%10 açığa dönerken, Avusturya, Finlandiya, Hollanda ve Almanya'nın bu yıllar içinde cari işlemleri ortalama GSYİH'nın \%2-3 arasında fazla vermiștir.

Birlik ülkeleri içinde döviz kuru ayarlamalarının mümkün olmadığı, ekonomi politikasında tam bir koordinasyoun bulunmadığı ve rekabet edebilme göstergeleri üzerinden politika belirleme mekanizmalarının eksik olduğu bir para birliği içinde cari işlemler dengesizliklerinin düzelmeyeceği hatta sürdürülemez boyutlara ulaşabileceği anlaşılmıştır.

- Tek para birimine rağmen Avro bölgesinde birleşik bir bankacılık sistemi bulunmamaktadır, bu da Avrupa bankacılığının kırılganlığını artırmaktadır.

Banka birliğinin olmaması, bankacılık sistemi ile hükümetler arasında karşılıklı bağımlılığı artırmaktadır. Bir taraftan likidite yetersizliği nedeniyle ödeme zorluğuna düşmüş ulusal bankalar ulusal hükümetlerin sorumluluğu altında iken diğer taraftan, kendi ülke hükümetlerinin borçlanma senetlerini tutma riskine maruz kalmaktadırlar.

- AMB'nın yasal "son borçlanma merci” özelliği bulunmamasıdır.

Ulusal hükümetlerin merkez bankasından borçlanamamaları, likidite ve ödeme kabiliyetinin azalması krizlerine karşı Avro bölgesi ülkelerini savunmasız hale getirmiştir. Üye ülkeler, ulusal piyasalardan likiditenin çekilmesi durumunda ödeme sorunu ile karşılaştıklarında, ihtiyaç duydukları likiditeyi yüksek faiz oranlarından sağlayacak finansal piyasalara muhtaç kalmışlardır. Bir ülkenin böylesi bir durumda olduğu anda piyasa algısı, ekonomik durumu benzer olan diğer ülkelere de çevrilir. Yunanistan'da başlayan krizin diğer çevre ülkelere de yansımasının temel nedenlerinden biri de budur.

Ayrıca nominal döviz kuru aracının yokluğu, ortak para kullanımında sadece makroekonomik ayarlamalar için zorluk yaratmamakta; aynı zamanda mali politikanın da çok fazla hareket alanı bulamaması anlamına gelmektedir. Öncelikle Maastrich Anlaşması üye ülkelerin mali politika esnekliklerini kısıtlamıştır. Ancak yine de AB'de önemli sayılacak merkezi bir bütçe bulunmamaktadır. Üye ülkelerin kendi bütçeleri, $A B^{\prime}$ nin bütçesinin büyümesini engellemektedir. Hükümetler, ulusal güvenlik ve sosyal refah

Sayfa/Page | 179

İGÜSBD

Cilt: 2 Sayı: 2

Ekim /

October 2015 
Sayfa/Page | 180 İGÜSBD Cilt: 2 Sayı: 2

harcamaları gibi tipik kamu bütçelerine büyük aktarımlar yapabilmektedirler. Yani şokların etkisini azaltabilecek bir harcama enstrümanı mevcut değildir. Diğer taraftan entegrasyona dayalı teori, emek piyasalarındaki düşük büyüme/yüksek işsizlik bölgelerinden yüksek büyüme/düşük işsizlik bölgelerine bir mobilizasyon olacağını öngörse de, Birlik ülkeleri arasındaki emek mobilizasyonu (son krizde kısmi bir artışın yaşandığı görülse de) kültür ve dil farkları nedeniyle beklenen düzeyde olmamıştır. Bu nedenlerden dolayı ayarlamalar ancak ücret ve fiyatlardaki değişiklikler ile meydana gelen reel döviz kurundaki değişikliklerle mümkün olabilecektir.

Bir diğer neden APB'ne giriş için gerekli olan Maastricht kriterlerinin, mali ayarlamanın kalitesine ya da yöntemine bakılmaksızın sayısal hedeflere odaklanmış olmasıdır. Aslında makroekonomik politikalar için disiplin unsuru olacağı düşünülen bu tür kriterlere uyma gerekliliği, birleșim öncesi dönemde "katı-koşulluluk" altında izlenirken, APB döneminde "esnek koşulluluk"a dönmüştür. ${ }^{16}$ Ancak kriz sonrasında bir takım değişikliklere de gidilmiştir. Örneğin ulusal mali bütçeler değerlendirilirken muhasebe kuralları uyumuna, istatistiki raporlamalara, tahmin hesaplamalarına, mali kurallara, bütçe prosedürlerine, bölgesel veya yerel otoriteler gibi kamu birimleri arasındaki mali ilişkiler de dâhil olmak üzere çok yönlü göstergelere de bakılması yönünde fikir birliği oluşmuştur. Ayrıca makroekonomik dengesizliklerin takibinde de, $\mathrm{AB}$ komisyonun daha geniş bir kontrolünün gerekliliği vurgulanmıştır. ${ }^{17}$

Özetle, Yunanistan'ın mali borcunun pek çok içsel nedenleri olsa da böylesi sorunlu dinamiklerin bulunduğu yapı içerisinde, ülkenin ekonomik olarak rekabet edebilirliğinin giderek zayıflaması göz ardı edilmemelidir. Entegrasyon ile birlikte faizlerin düşmesi tüketimin finansmanına hizmet etmiş, rekabet edebilirliği olumsuz etkilemiştir. Enflasyonun da artması Yunanistan'da reel döviz kurunu değerlendirme yoluyla rekabet edebilirliğini daha da düşürmüştür. Diğer tarafta ise Almanya ücret maliyetlerini düşürme yönünde uygulamalarıyla, kendi reel döviz kurunu değersizleştirerek rekabetçi pozisyonunu avantajlı konuma getirmiştir. ${ }^{18}$

\section{Saptamaların Değerlendirilmesi}

APB'nin sorunlu dinamikler üretmesi ile ilgili krize giren ve girmeyen ülkelerin ekonomik göstergelerini değerlendirmek analiz için yararlı olacaktır.

\footnotetext{
${ }^{16}$ Katsimi ve Moutos, 2010, s. 573; Bu esneklik ile Yunanistan, 2000-08 yılları arasında bütçe açı̆̆ı üzerindeki sınırı her yıl \%3 ihlal etti.

${ }^{17}$ Featherstone, 2011 s. 209.

18 Kaelberer, 2012, s. 428.
} 
Tablo 1: 1995-2008 Arası GSYİH ve Yurtiçi Talepte Büyüme

\begin{tabular}{|l|l|l|l|l|l|l|}
\cline { 2 - 7 } \multicolumn{1}{c|}{} & Yunanistan & Almanya & Hollanda & İspanya & Fransa & İrlanda \\
\hline Reel GSYİH & $61,0 \%$ & $19,5 \%$ & $42,0 \%$ & $56,0 \%$ & $30,8 \%$ & $124,1 \%$ \\
\hline $\begin{array}{l}\text { Reel Özel } \\
\text { Tüketim }\end{array}$ & $55,7 \%$ & $12,3 \%$ & $33,1 \%$ & $55,3 \%$ & $33,5 \%$ & $104,5 \%$ \\
\hline $\begin{array}{l}\text { Reel } \\
\text { Toplam } \\
\text { Sermaye } \\
\text { Yatırımı }\end{array}$ & $102,8 \%$ & $18,8 \%$ & $56,3 \%$ & $95,2 \%$ & $55,8 \%$ & $130,5 \%$ \\
\hline $\begin{array}{l}\text { Reel Kamu } \\
\text { Tüketimi }\end{array}$ & $51,1 \%$ & $14,7 \%$ & $41,4 \%$ & $74,8 \%$ & $20,0 \%$ & $97,3 \%$ \\
\hline
\end{tabular}

\begin{tabular}{|l|l|l|l|l|l|l|}
\hline $\begin{array}{l}\text { (2008) Cari } \\
\text { İşlemler / } \\
\text { GSYIH }\end{array}$ & $-14,6 \%$ & $6,7 \%$ & $4,8 \%$ & $-9,6 \%$ & $-2,3 \%$ & $-5,2 \%$ \\
\hline
\end{tabular}

\begin{tabular}{|l|l|l|l|l|l|l|}
\hline $\begin{array}{l}\text { İhracat } \\
\text { Hacmi (mal } \\
\text { ve } \\
\text { hizmetler) }\end{array}$ & $131,4 \%$ & $159,0 \%$ & $114,1 \%$ & $115,1 \%$ & $76,0 \%$ & $232,3 \%$ \\
\hline $\begin{array}{l}\text { İthalat } \\
\text { Hacmi (mal } \\
\text { ve } \\
\text { hizmetler) }\end{array}$ & $123,1 \%$ & $115,5 \%$ & $117,8 \%$ & $174,1 \%$ & $101,8 \%$ & $222,4 \%$ \\
\hline $\begin{array}{l}\text { İhracat } \\
\text { Fiyatları } \\
\text { (mal ve } \\
\text { hizmetler) }\end{array}$ & $56,4 \%$ & $2,7 \%$ & $18,0 \%$ & $34,2 \%$ & $7,2 \%$ & $13,2 \%$ \\
\hline $\begin{array}{l}\text { İthalat } \\
\text { Fiyatları } \\
\text { (mal ve } \\
\text { hizmetler) }\end{array}$ & $51,0 \%$ & $9,3 \%$ & $14,3 \%$ & $28,4 \%$ & $7,9 \%$ & $20,9 \%$ \\
\hline
\end{tabular}

Kaynak: Milios, John, Dimitris P. Sotiropoulos, s: 228.

Çevre'deki (Yunanistan, İspanya, İrlanda) ülkelerin 1998-2008 yılları arasında yüksek reel büyüme rakamlarıyla merkezdeki gelişmiş (Almanya, Hollanda, Fransa) ülkelere yüksek karlar ve yüksek yatırımlarla yaklaştığı görülse de bu yüksek büyüme rakamları diğerlerine göre daha yüksek enflasyon ve cari açık ile birlikte ortaya çıkmıştır. Kamunun ve özel sektörün reel tüketim artışı farklılığı belirgindir.

Sayfa/Page | 181 
Tablo 2: Cari İşlemler Dengesi/GSYİH (\%): 1995-2012

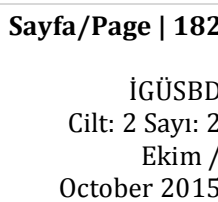

\begin{tabular}{|l|l|l|l|l|l|l|l|}
\hline & $\mathbf{1 9 9 5}$ & $\mathbf{2 0 0 0}$ & $\mathbf{2 0 0 5}$ & $\mathbf{2 0 0 7}$ & $\mathbf{2 0 0 8}$ & $\mathbf{2 0 1 0}$ & $\mathbf{2 0 1 2}$ \\
\hline Almanya & $-1,17$ & $-1,83$ & 4,99 & 7,48 & 6,19 & 6,12 & 7,03 \\
\hline İlanda & 2,58 & $-0,32$ & $-3,48$ & $-5,33$ & $-5,61$ & 1,14 & 4,42 \\
\hline Yunanistan & $-2,69$ & $-7,80$ & $-7,60$ & $-14,64$ & $-14,95$ & $-10,22$ & $-3,49$ \\
\hline İspanya & $-0,32$ & $-3,97$ & $-7,36$ & $-9,99$ & $-9,62$ & $-4,49$ & $-1,11$ \\
\hline Fransa & 0,70 & 1,44 & $-0,47$ & $-0,97$ & $-1,77$ & $-1,36$ & $-2,21$ \\
\hline & & & & & & & \\
İtalya & 2,04 & $-0,53$ & $-1,65$ & $-2,43$ & $-2,88$ & $-3,53$ & $-0,55$ \\
\hline Portekiz & - & $-10,36$ & $-10,70$ & $-10,09$ & $-12,64$ & $-10,57$ & $-1,53$ \\
\hline
\end{tabular}

Kaynak: http://ec.europa.eu/eurostat/web/balance-of-payments/data/database

Çevre ülkelerin hepsinin ortak özelliği, Avro bölgesinde ulusal ekonomilerinin rekabet edebilirliliklerini kaybetmeleri nedeniyle ortaya çıkan dış ödemeler dengesi açıklarıdır. Ortak para birimine geçildiğinde, ayarlama maliyetlerinin ülkeler arasında daha adil dağıtılacağına dair bir beklenti bulunmakla beraber ödemeler dengesi sorunlarını çözmeye yönelik nominal döviz kuru aracı kullanılamadığından, açık veren ülkelerin ortak para biriminde ayarlama maliyetlerini daha fazla yüklendikleri ortaya çıkmıștır. ${ }^{19}$ Tablo 2, nominal döviz kurları sabitlendikten sonra çevredeki ülkelere kıyasla rekabet edebilirliğin artıracak bir reel döviz kuru devalüasyonunun, Almanya'nın dış dengesi için ne kadar yararlı olduğunu göstermektedir. Söz konusu cari işlem fazlaları, Almanya'nın büyümesinin temel kaynağı olmuştur.

Tablo 3. Kamu Açıkları ve Borçlanma: Genel Kamı Açığı/Fazlası GSYìH'ya Oranı (\%)

\begin{tabular}{|l|l|l|l|l|l|l|l|l|l|l|l|l|l|}
\hline & $\mathbf{2 0 0 1}$ & $\mathbf{2 0 0 2}$ & $\mathbf{2 0 0 3}$ & $\mathbf{2 0 0 4}$ & $\mathbf{2 0 0 5}$ & $\mathbf{2 0 0 6}$ & $\mathbf{2 0 0 7}$ & $\mathbf{2 0 0 8}$ & $\mathbf{2 0 0 9}$ & $\mathbf{2 0 1 0}$ & $\mathbf{2 0 1 1}$ & $\mathbf{2 0 1 2}$ & $\mathbf{2 0 1 3}$ \\
\hline Almanya & $-3,10$ & $-3,90$ & $-4,10$ & $-3,70$ & $-3,30$ & $-1,50$ & 0,30 & - & $-3,00$ & $-4,10$ & $-0,90$ & 0,10 & 0,10 \\
\hline İrlanda & 0,90 & $-0,30$ & 0,40 & 1,40 & 1,60 & 2,80 & 0,20 & $-7,00$ & $-13,9$ & $-32,4$ & $-12,6$ & $-8,00$ & $-5,70$ \\
\hline Yunanistan & $-4,50$ & $-4,80$ & $-5,60$ & $-7,50$ & $-5,20$ & $-6,10$ & $-6,70$ & $-9,90$ & $-15,2$ & $-11,1$ & $-10,1$ & $-8,60$ & $-12,2$ \\
\hline İspanya & $-0,50$ & $-0,40$ & $-0,40$ & - & 1,20 & 2,20 & 2,00 & $-4,40$ & $-11,0$ & $-9,40$ & $-9,40$ & $-10,3$ & $-6,80$ \\
\hline Fransa & $-1,40$ & $-3,10$ & $-3,90$ & $-3,50$ & $-3,20$ & $-2,30$ & $-2,50$ & $-3,20$ & $-7,20$ & $-6,80$ & $-5,10$ & $-4,90$ & $-4,10$ \\
\hline İtalya & $-3,40$ & $-3,10$ & $-3,40$ & $-3,60$ & $-4,20$ & $-3,60$ & $-1,50$ & $-2,70$ & $-5,30$ & $-4,20$ & $-3,50$ & $-3,00$ & $-2,80$ \\
\hline Portekiz & $-4,80$ & $-3,30$ & $-4,40$ & $-6,20$ & $-6,20$ & $-4,30$ & $-3,00$ & $-3,80$ & $-9,80$ & $-11,2$ & $-7,20$ & $-5,50$ & $-4,90$ \\
\hline
\end{tabular}

Kaynak: http://ec.europa.eu/eurostat/web/government-finance-statistics/data/ database

${ }^{19}$ Kaelberer, 2012, s. 429. 
Kamu açıklarına dayanan kriz açılamalarının, Tablo 3.'de yer alan Yunanistan ve Portekiz için geçerli olduğu görülse de, krize kadar İrlanda ve İspanya kamu fazlası vermiş, kriz sonrasında da fazla, açığa dönmüş ve giderek artmıştır. Ancak yine de göstergeler, borçlanma oranlarında ciddi artışlar olduğunu da işaret etmektedir. ${ }^{20}$

Tablo 4. Borçlanma Maliyetleri (Bono Faizleri) (\%)

\begin{tabular}{|l|l|l|l|l|l|l|l|l|l|l|l|l|}
\hline $\begin{array}{l}\text { Bono } \\
\text { Faizleri }\end{array}$ & $\mathbf{2 0 0 1}$ & $\mathbf{2 0 0 3}$ & $\mathbf{2 0 0 5}$ & $\mathbf{2 0 0 7}$ & $\mathbf{2 0 0 8}$ & $\mathbf{2 0 0 9}$ & $\mathbf{2 0 1 0}$ & $\mathbf{2 0 1 1}$ & $\mathbf{2 0 1 2}$ & $\mathbf{2 0 1 3}$ & $\begin{array}{l}\mathbf{2 0 1 4} \\
*\end{array}$ & $\begin{array}{l}\mathbf{2 0 1 5} \\
* *\end{array}$ \\
\hline $\begin{array}{l}\text { AB 27 } \\
\text { Ülke }\end{array}$ & 5,00 & 4,23 & 3,74 & 4,56 & 4,54 & 4,12 & 3,82 & 4,30 & 3,68 & 2,95 & 1,95 & 1,25 \\
\hline Almanya & 4,80 & 4,07 & 3,35 & 4,22 & 3,98 & 3,22 & 2,74 & 2,61 & 1,50 & 1,57 & 0,96 & 0,35 \\
\hline İlanda & 5,01 & 4,13 & 3,33 & 4,31 & 4,53 & 5,23 & 5,74 & 9,60 & 6,17 & 3,79 & 1,98 & 1,17 \\
\hline Yunanistan & 5,30 & 4,27 & 3,59 & 4,50 & 4,80 & 5,17 & 9,09 & 15,75 & 22,50 & 10,05 & 6,77 & 9,60 \\
\hline İspanya & 5,12 & 4,12 & 3,39 & 4,31 & 4,37 & 3,98 & 4,25 & 5,44 & 5,85 & 4,56 & 2,36 & 1,53 \\
\hline Fransa & 4,94 & 4,13 & 3,41 & 4,30 & 4,23 & 3,65 & 3,12 & 3,32 & 2,54 & 2,20 & 1,40 & 0,64 \\
\hline İtalya & 5,19 & 4,25 & 3,56 & 4,49 & 4,68 & 4,31 & 4,04 & 5,42 & 5,49 & 4,32 & 2,57 & 1,63 \\
\hline $\begin{array}{l}\text { Güney } \\
\text { Kıbris }\end{array}$ & 7,63 & 4,74 & 5,16 & 4,48 & 4,60 & 4,60 & 4,60 & 5,79 & 7,00 & 6,50 & 6,00 & 6,00 \\
\hline Portekiz & 5,16 & 4,18 & 3,44 & 4,42 & 4,52 & 4,21 & 5,40 & 10,24 & 10,55 & 6,29 & 3,33 & 2,41 \\
\hline
\end{tabular}

Kaynak: http://ec.europa.eu/eurostat/web/interest-rates/database $(* 2014$ için 5-12. aylar arası ortalaması, ${ }^{* *} 2015$ için 1-2. aylar ortalaması)

Avrupa'nın çevre ekonomileri kriz ile birlikte ekonomik faaliyetlerin gerilemesi, işsizlikte artış, kamu açıklarında büyüme ile karşılaştılar. Bono faizleri 2009 itibariyle çevre ülkelerinde artarak, merkez ülkelerin faizleriyle aradaki farkı da giderek açtı. Bu gelişme, Avro bölgesinin ilk yıllarındaki eğilimi de tersine çevirmiş oldu.

Tablo 5. Tüketici Fiyat Endeksi, (TÜFE 1996=100)

\begin{tabular}{|c|c|c|c|c|}
\hline & $\mathbf{2 0 0 0}$ & $\mathbf{2 0 0 5}$ & $\mathbf{2 0 0 9}$ & $\mathbf{2 0 1 3}$ \\
\hline Almanya & 103,60 & 111,30 & 120,20 & 128,70 \\
\hline İrlanda & 108,20 & 129,30 & 142,10 & 142,90 \\
\hline Yunanistan & 113,20 & 135,80 & 152,70 & 167,40 \\
\hline İspanya & 107,00 & 125,00 & 140,40 & 152,80 \\
\hline Fransa & 103,30 & 113,50 & 122,40 & 131,30 \\
\hline İtalya & 106,90 & 120,00 & 130,70 & 142,90 \\
\hline
\end{tabular}

20 Milios ve Sotiropoulos, 2010 s. 230; 1990’larda Yunanistan'da reel faiz oranı ortalama 5.4 iken, 2000 sonrasında neredeyse 0'a düştü ve uzunca bu seviyede kaldı. 
Sayfa/Page | 184 İGÜSBD Cilt: 2 Sayı: 2 October 2015

\begin{tabular}{|c|c|c|c|c|} 
& $\mathbf{2 0 0 0}$ & $\mathbf{2 0 0 5}$ & $\mathbf{2 0 0 9}$ & $\mathbf{2 0 1 3}$ \\
\hline Portekiz & 107,30 & 125,90 & 136,60 & 147,10 \\
\hline
\end{tabular}

Kaynak: http://ec.europa.eu/eurostat/web/hicp/data/database

Ortak para kullanımı ile birlikte enflasyon oranlarının da biribirine yakınsayacağı varsayılmış, nominal kurların Avro'ya sabitlenmesi yoluyla yüksek enflasyonlu ülkelerin anti-enflasyonist güvenirlilik kazanacakları beklenmiştir. ${ }^{21}$ Ancak Tablo 5'teki enflasyon verilerine bakıldı̆̆ında bunun gerçekleşmediği görülmektedir. Tabloda yer alan ülkelerin enflasyon oranlarındaki artış 1996-2000 yılları arasında birbirlerine yakınken, 2005 yılı sonrasında Fransa dâhil olmak üzere tüm ülkelerin enflasyon oranı Almanya'nın enflasyon oranından daha yüksek oranlarda artış kaydetmiştir.

\section{Sonuç ve Değerlendirme}

Krizi açıklamaya çalışan akademik ve siyasi çevreler, nedenleri ya tamamen Yunanistan'a ya da tamamen Avrupa Para Birliği'nin oluşturduğu yapının sorun yaratma potansiyeli taşıyan dinamiklerine bağlamaktadır. Böylesi bir yapı içerisinde ortaya çıkan düşük faizler, rekabet gücünde ortaya çıkan farklılıklar, merkez ülkelerin dış ticaret, üretim, istihdam politikalarıyla çevre ülkelerin politikalarının farklılıkları temel nedenler olmakla birlikte, bu yapının getirmiş olduğu katılık ve esneklikleri çevre ülkelerin kendi lehlerine çevirmeye çalıştıkları da yadsınamaz.

$\mathrm{Bu}$ çalışmada her iki sorun kaynağı da ele alınmaya ve tespitler yapılmaya çalışılmıştır. "Ülke borç krizi” tanımlaması tek bir suçlu belirlerken, ödemeler dengesi krizi yaklaşımı her iki tarafı da sorumlu olarak kabul eder.

Ortak para birliği içindeki ülkelerde ödemeler dengesi krizi, birbiriyle içiçe geçmiş bir olgu olarak karşımıza çıkmaktadır: bir ülkenin fazlası diğerinin açığıdır; bir ülkenin borcu diğerinin aşırı tasarrufudur; bir ülkedeki aşırı tüketim, diğer ülkede tüketim azlığı anlamına gelir. Bunun sistematik etkisi, sermayenin ticaret fazlası veren ülkelerden açık veren ülkelere kaymasıdır. Spekülatif sermaye de bu sayede çevre ülkelerdeki gayrimenkul balonlarının ve yurtiçi enflasyonun oluşmasına katkıda bulunmuştur. Özetle çevre ülkelerinin finansal hesaplarındaki fazlalar, cari işlem açılarının artmasının temel nedeni olmuştur. Çevrenin büyüme rakamları merkezin tasarruflarını cezbederek, çevrenin artan talebinin finansmanını da sağlamaktadır. Ayrıca merkezin daha rekabetçi ülkelerindeki sermaye yatırımları çevrenin finansal sistemlerinde yüksek karlar elde ederek çevre

${ }^{21}$ Kaelberer, 2012, s. 433. 
ülkelerin büyüme oranlarına ve merkezin ihracatının finansmanına katkıda bulunmaaktadır.

Almanya neo-merkantilist bir stratejiyle rekabet pozisyonunu sabit döviz kuru sistemi içinde sağlayabilmiş; ticaret yaptığg ülkelerin aleyhine işleyen bir politika yürütmüştür. Daha genel bir ifadeyle merkezdeki ülkeler, ihracatlarını avro bölgesi içinde geliştirmişler ve bu durum daha az rekabetçi seviyede olan çevrenin verimlilik temellerini ve ekonomik gelişmelerini geriletici bir etki yaratmıştır.

Almanya'nın krizi çözmek konusunda önerisi ise borçlu ülkelerin sorumluluğuna vurgu yapmak olmuştur. ${ }^{22}$ Bunlar mali sıkılık, borçlar için koşulluluk, ücret endeksleme sisteminin kaldırılması, borçlu ülkelere karşı müeyyideler, emeklilik sistemini ve kurumlar vergisi sistemini uyumlaştırmaktır. Borç krizi yaklaşımı ile bakıldığında sorun, borçlu ülke tarafından ele alınarak çözülmelidir.

Krizin ödemeler bilançosu dengesizlikleri nedeniyle ortaya çıtığını ve şiddetlendiğini söyleyenler ise çevre ülkelerin endüstriyel yapılarını güçlendiren, vasıf-artırıcı eğitim kurumlarına yatırımı veya hükümetlerin kurumsal yapılarını reforme etme gibi modernizasyon çabalarına, finansal destekler olarak yapısal fonları güçlendirmeleri önerilmektedir. Özellikle Yunan siyası yapısının modernizasyonu, ekonomik gelişmeyi zedeleyen klientalistik ilişkilerin sonlanmasına yarayacaktır. Reel döviz kurunun değersizleşmesinin verimlilik kazançlarıyla gerçekleşmesi, bunun ücret kesintileri ve kemer sıkma politikalarıyla uygulanmasından siyasi olarak daha kabul edilebilir ve yapıcı bir strateji olacaktır.

Son olarak AMB'nın son borçlanma mercii fonksiyonunu işler hale getirmesi önerilmiştir ki, bu hem finansal istikrara katkıda bulunacak hem de çevre ülkelerinin borçlanma maliyetlerini azaltacaktır. ${ }^{23}$

22 Featherstone, 2011, s. 61, Alman gazeteleri tepkilerini, Yunanistan'ın adaları ya da Acropol'ü satarak borçlarını ödemesi gerekir gibi ifadelerle yansıttılar.

23 Kaelberer, 2012, s. 430. 


\section{KAYNAKÇA}

FEATHERSTONE, Kevin, 'External conditionality and the debt crisi: the Troika and public administration reform in Greece', Journal of European Public Policy, Vol 22, No 3, 2015.

Sayfa/Page | 186 İGÜSBD Cilt: 2 Sayı: 2 October 2015

FEATHERSTONE, Kevin, 'The Greek Sovereign Debt Crisis and EMU: A Failing State in a Skewed Regime', Journal of Common Market Studies, vol 49, no 2, 2011.

HELD, David ve Anthony McGrew, "Globalization and the Liberal Democratic State", Government and Opposition, vol 28, no 2, 1993.

HENIG, Stanley, 'The Mediterranean Policy of the European Community", The New Politics of European Integration, edt. Ghita Ionescu, MacMillan St Martin's Press, 1972.

HOLMAN, Otto, Integrating Southern Europe, EC Expansion and Transnationalization of Spain, Routledge, London, 1996.

KAELBERER, Matthias, 'Sovereign Debt or Balance of Payments Crisis? Exploring the Structural Logic of Adjustment in the Eurozone", Journal of Balkan and Near Eastern Studies, Vol 16, No 4, 2012.

KATSELI, Louka, "Economic Integration in the Enlarged European Community: Structural Adjustment of the Greek Economy", Unity with Diversity in the European Economy: the Community's Southern Frontier, edt. C. Bliss ve J. Braga de Macedo, Cambridge University Press, Cambridge, 1990.

KATSIMI, Margarita, Thomas MOUTOS, 'Emu and the Greek crisis: The political-economy perspective”, European Journal of Political Economy, 26, 2010.

KITOMILIDES, Yiannis, "Stories, Fables, Parables, and Myths: Greece and the Euro Crisis, Toward a new Narrative", Journal of Economic Issues, Vol XLVII, No 2, Sept 2013.

LEKAKIS, Joseph, Maria KOUSIS, 'Economic Crisis, Troika and the Environment in Greece", South European Socety and Politics, Vol 18, No 3, 2013.

MARAVALL, Jose Maria, Regimes, Politics and Markets, Democratization and Economic Change in Southern and Eastern Europe, Oxford University Press, 1997.

MARKANTONATOU, Maria, 'The State and Modes of Regulation in Greece from Post-War Period to 2009 Financial Crisis', Journal of Balkan and Near Eastern Studies, Vol 14, No 4, December 2012.

MICHAEL-MATSAS, Savas, 'Greece and the World Capitalist Crisis', Critique, Vol 38, No 3, August 2010.

MILIOS, John, Dimitris P. SOTIROPOULOS, 'Crisis of Greece or crisis of the euro? A view from the Europhean periphery', Journal of Balkan and Near Eastern Studies, Vol 12 No 3, September 2010. 
TSAROUHAS, Dimitris, "The Political Origins of the Greek Crisis: Domestic Failures and the EU Factor", Insight Turkey, Vol.14, No 2, 2012.

VISVIZI, Anna, 'From Grexit to Grecovery: the Paradox of Troika's Engagement with Greece', Perspectives on European Politics and Society, vol 15, no 3, 2014. 
Sayfa/Page | 188 İGÜSBD Cilt: 2 Sayı: 2 October 2015

\section{Summary}

The statements regarding the main reasons of sovereign debt crisis of academic and political actors depend on either wholly to Greece or to the problematic potentials of the structure established by EMU. In this kind of monetary union, the low interest rates, differences in competitiveness of the countries as from the foreign trade, production and employment policies of the center and the periphery are the main argument points. On the contrary we can not exclude the advantage seeking facilities of the periphery under these kind of strict and flexible rules of the monetary structure. The question is very simple: what is the main reason of sovereign debt crisis. Is it the only the country itself by the false policies designed and executed or is it the response of both sides regarding the balance of payment disequlibrium. If one partner has a surplus, the other has a deficit; if one has an excess debtness, the other has an excess savings; if one has over consumption, the other has under consumption. Systematically financial capital moves from the surplus countries to the deficit ones, which leads domestic inflation and baloons and in turn increasing current account deficits.

This article focused on the leading countries in the center such as Germany have expanded their export in Eurozone which consequently have a negative impact upon productivity and economic development of the periphery countries, such as Greece. So the stabilization path should strengthen the industrial structure, improve the technical qualification of labour and modernize the institutional power of the governments of the periphery by financial supports and funds of the members in the center. 